Article

\title{
Eco-Friendly Education Facilities: The Case of a Public Education Building in South Korea
}

\author{
Eunil Park ${ }^{1}$ (1) and Angel P. del Pobil ${ }^{1,2, *}$ \\ 1 Department of Interaction Science, Sungkyunkwan University, Seoul 03063, Korea; pa1324@gmail.com or \\ eunilpark@skku.edu \\ 2 Department of Computer Science and Engineering, Jaume-I University, 12071 Castellón, Spain \\ * Correspondence: pobil@uji.es; Tel.: +34-964-72-82-93
}

Received: 23 August 2018; Accepted: 20 September 2018; Published: 25 September 2018

\begin{abstract}
Since the importance and effects of national energy policies, plans, and roadmaps were presented in South Korea, the role of renewable energy resources has received great attention. Moreover, as there is significant reasoning for reducing and minimizing nuclear and fossil fuel usage in South Korean national energy plans, several academic scholars and implementers have expended significant effort to present the potential and feasibility of renewable energy resources in South Korea. This study contributes to these efforts by presenting potential sustainable configurations of renewable energy production facilities for a public building in South Korea. Based on economic, environmental, and technical information as well as the presented simulation results, it proposes an environmentally friendly renewable energy production facility configuration that consists of photovoltaic arrays, battery units, and a converter. Subsidies for installing and renovating such facilities are also considered. The potential configuration indicates $\$ 0.464$ as the cost of energy, $100 \%$ of which is renewable. Potential limitations and future research areas are suggested based on the results of these simulations.
\end{abstract}

Keywords: eco-friendly; renewable energy; energy subsidies; SEMS; South Korea

\section{Introduction}

After the peaceful turnover of political power in 2017, the new South Korean government is attempting to reform national energy policies and plans. During this reform process, the government is aiming to phase out the usage of nuclear energy. One of the major decisions undertaken in this regard was the suspension of the construction of the fifth and sixth nuclear reactors in Kori when the construction process was $28.8 \%$ complete [1]. Although construction resumed when the government was implored to do so by a jury of 471 randomly selected citizens, the government decided that no new nuclear power plants in South Korea should be constructed [2].

Therefore, exploring, adopting, and using new energy resources is one of the most important research areas for establishing national energy policies and plans. As nuclear energy constitutes approximately $12 \%$ of South Korea's national energy supply system, alternative energy resources could be unpalatable or infeasible [3]. Moreover, because of the Paris Agreement, which requires South Korea to reduce its large greenhouse gas emissions, increasing the use of fossil fuels would also be infeasible [4].

Accordingly, the South Korean government is aiming to implement renewable energy resources. Approximately $4.6 \%$ of primary energy in South Korea was provided by renewable energy production facilities in 2015, with an annual growth rate of 15.2\% [3]. Moreover, South Korea's energy dependence on foreign countries is very high, and compared with other countries, oil price fluctuations have 
a greater effect on the South Korean economy [5]. Thus, ensuring reliable energy production and securing stable energy resources are important.

The South Korean government has pursued the expansion and distribution of renewable energy production facilities to achieve its goal that, by $2035,11 \%$ of primary energy in South Korea should be generated from renewable energy resources. To achieve this goal, the government established The fourth basic plans for the technology development, usage, and distribution of new and renewable energy, with detailed programs for promoting each energy source [6]. Based on these promotion programs, the duty ratio of the renewable portfolio standards was revised and enhanced. All public buildings with a certain total floor area that are planned to be constructed, reconstructed, or enlarged should have at least $21 \%$ of their energy supplied by renewable resources [7]. Therefore, both central and local South Korean governments urge public organizations and institutions to include electricity and energy production facilities that use renewable resources. For this reason, several studies have attempted to investigate the feasibility of implementing renewable energy production facilities in diverse public buildings, including a public university, local government office, and multi-purpose public buildings [8].

Considering this background, this paper presents a case study for the economic and environmental feasibility of renewable energy production systems in a public education building in South Korea. After careful simulation, a potential configuration of a renewable energy production system for the building is suggested.

\section{Review of Prior Feasibility Studies in South Korea}

Several studies have attempted to investigate the feasibility of renewable-oriented power generation facilities in South Korea. Table 1 summarizes the key prior studies. As presented in Table 1, the majority of prior studies have focused on specific regions such as certain islands or areas. This means that only a few studies have explored the sustainable cases of renewable energy facilities for public buildings in South Korea.

Table 1. Summary of prior feasibility studies of renewable energy facilities conducted in South Korea (W: Wind turbines, P: photovoltaic (PV) arrays, D: Diesel generators, B: Battery units, C: Converters, $\mathrm{K}$ : Kerosene generators).

\begin{tabular}{|c|c|c|c|}
\hline Target Location & Suggested Configurations & $\begin{array}{l}\text { Cost of Energy } \\
\text { (\$ per kWh) }\end{array}$ & Sources \\
\hline Jeju (island) & W-P-D-B-C systems & 0.174 & [9] \\
\hline Busan Asiad Main Stadium (sports complexes) & W-P-D-B-C systems & 0.491 & [10] \\
\hline Hongdo (island) & K-W-D-B-C systems & 0.303 & {$[11]$} \\
\hline Jeju World Cup Venue (sports complexes) & W-P-B-C systems & 0.405 & [12] \\
\hline Gadeokdo (island) & W-P-B-C systems & 0.326 & [13] \\
\hline Semiconductor facilities (industrial facilities) & P-B-C systems & 0.668 & [14] \\
\hline Kyung-Hee University (education facilities) & W-P-B-C systems & 0.509 & {$[15]$} \\
\hline Geojedo (island) & W-P-B-C systems & 0.472 & [16] \\
\hline Gasado (island) & W-P-B-C systems & 1.284 & [17] \\
\hline
\end{tabular}

\section{Case Study: Research Background}

\subsection{Location and Facilities}

This study focused on an elementary school located in southeastern South Korea. To investigate the economic and environmental feasibility of potential renewable energy production facility configurations for school buildings, this study selected Samrangjin Elementary School in Miryang (SESM), which has smart meter facilities to record the school's hourly electricity usage. The location of this school is $35^{\circ} 23^{\prime} 44.76^{\prime \prime} \mathrm{N}$ and $128^{\circ} 50^{\prime} 15.89^{\prime \prime} \mathrm{E}$, and it has approximately 100 students and 40 members of staff. The school has four buildings: the main education building, education support building, 
warehouse, and kindergarten building. Figure 1 presents the location and an overview of SESM in South Korea.

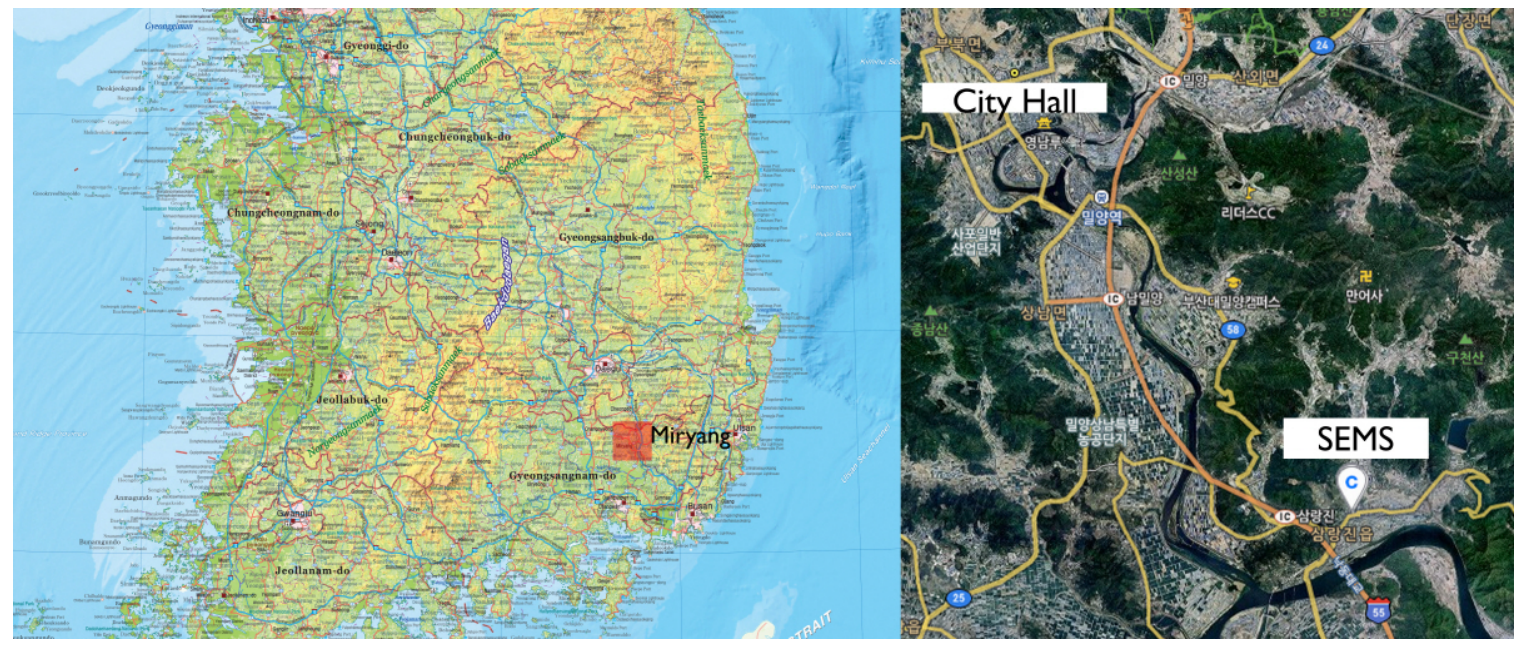

Figure 1. The location of SESM in South Korea.

\subsection{Energy Load Information}

SESM's energy system mainly uses electricity provided by the national grid. In 2016, SESM used 99,263 kWh. The SESM electricity load shows a scaled annual average electricity level of $223 \mathrm{kWh} / \mathrm{d}$ with a load factor of 0.464 .

\subsection{Renewable Energy Resources}

This study uses the solar resource data provided by the National Aeronautics and Space Administration (NASA). Table 2 summarizes the monthly baseline data. Annual average solar daily radiation is $4.259 \mathrm{kWh} / \mathrm{m}^{2} / \mathrm{d}$, with a solar clearness index of 0.514 . The wind resource information of SESM is collected and provided by the Korea Meteorological Administration. Figure 2 summarizes the monthly wind speed.

Table 2. Monthly solar resource information for SESM.

\begin{tabular}{|c|c|c|}
\hline Month & Solar Clearness Index & Solar Daily Radiation $\left(\mathrm{kWh} / \mathrm{m}^{2} / \mathrm{d}\right)$ \\
\hline January & 0.528 & 2.646 \\
\hline February & 0.513 & 3.255 \\
\hline March & 0.504 & 4.120 \\
\hline April & 0.547 & 5.428 \\
\hline May & 0.522 & 5.793 \\
\hline June & 0.498 & 5.744 \\
\hline July & 0.479 & 5.404 \\
\hline August & 0.499 & 5.159 \\
\hline September & 0.496 & 4.339 \\
\hline October & 0.539 & 3.706 \\
\hline November & 0.556 & 2.950 \\
\hline December & 0.547 & 2.515 \\
\hline
\end{tabular}




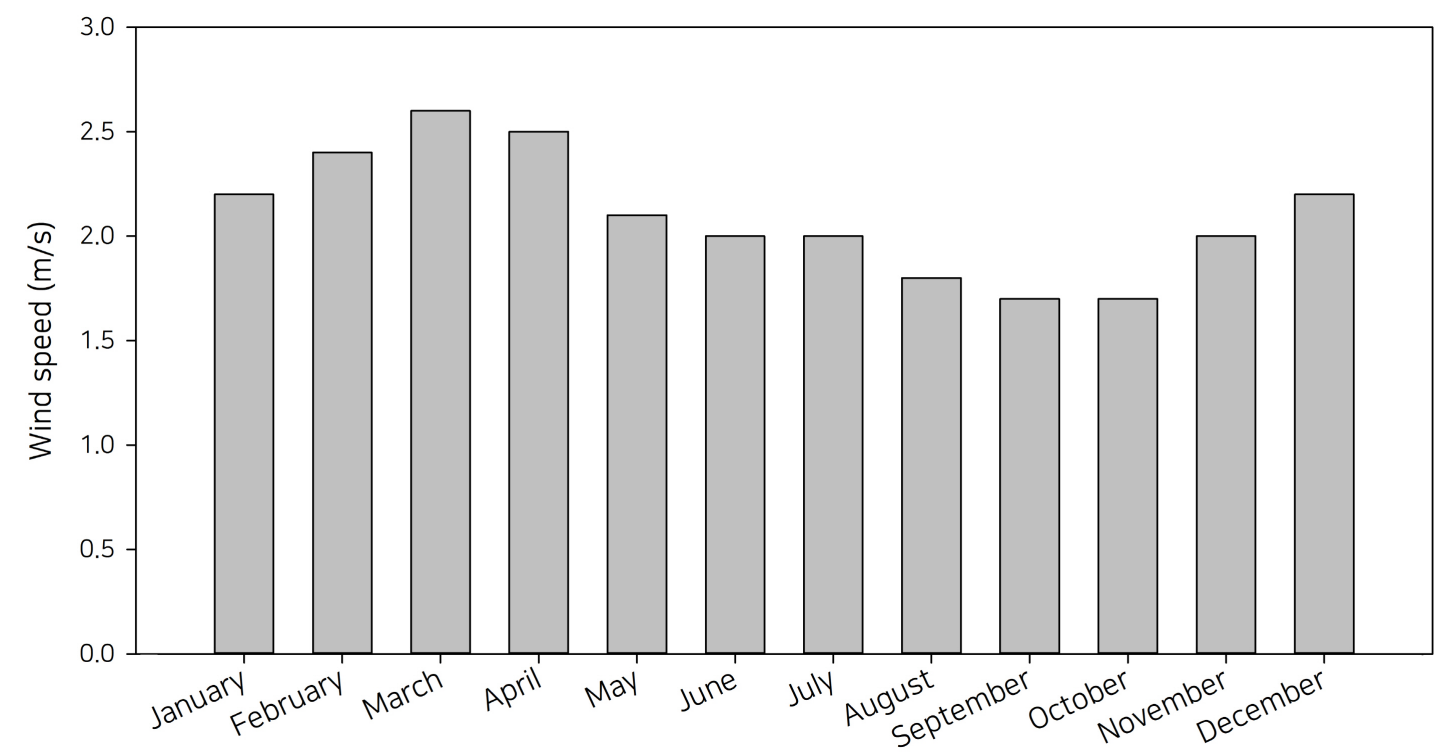

Figure 2. Average wind speeds at SESM.

\section{Simulation Parameters}

\subsection{Annual Real Interest Rate}

To present precise simulation results, the actual South Korean interest rate is computed and used in the simulations $[18,19]$. Based on a report by the Bank of Korea, an annual interest rate of $3.51 \%$ is used.

\subsection{Evaluation Criteria}

To explore the results of the simulation, the suggested sustainable configurations are ordered by two economic outputs: the cost of energy (COE) and net present cost (NPC). The COE is defined as the mean cost of generating $1 \mathrm{kWh}$ electricity by the suggested configuration, while the NPC is defined as the total cost of installing, utilizing, replacing, and performing the functions of the suggested configuration throughout the project [15]. In addition, the project lifespan used by this study is 25 years.

\section{Renewable Electricity Production Systems}

To introduce the configurations of the sustainable renewable energy production system, the economic information of each component that can be used in the configurations should be investigated. Based on detailed economic information about the components from previous studies, Table 3 summarizes the specific economic information about the components employed in the simulations presented here. In addition, the standard electricity price, which is introduced by KEPCO, is used in the grid connection. 
Table 3. Economic information about the components (* The supporting policies and plans by the South Korean government are applied).

\begin{tabular}{|c|c|c|c|c|c|}
\hline Component & Size & Cost Information & $\begin{array}{l}\text { Lifetime } \\
\text { (Years) }\end{array}$ & $\begin{array}{l}\text { Considered } \\
\text { Capacity }\end{array}$ & Others \\
\hline PV array & $1.0 \mathrm{~kW}$ & $\begin{array}{l}\$ 1500 \text { and } 750 * \text { (Capital), } \\
\$ 1500 \text { and } 750 * \text { (Replacement), } \\
\$ 25 \text { per year } \\
\text { (Operation \& management) }\end{array}$ & 20 & $0-600 \mathrm{~kW}$ & $\begin{array}{l}\text { Derating factor: } 80 \% \\
\text { reflectance: } 20 \%\end{array}$ \\
\hline Wind turbine & 1 unit & $\begin{array}{l}\$ 1960 \text { and } 980 * \text { (Capital), } \\
\$ 1960 \text { and } 980^{*} \text { (Replacement), } \\
\$ 30 \text { per year } \\
\text { (Operation \& management) }\end{array}$ & 20 & $0-2$ units & $\begin{array}{l}\text { Model: Generic } 1 \mathrm{~kW} \text { turbine } \\
\text { Hub height: } 25 \mathrm{~m}\end{array}$ \\
\hline Battery (S6CS25P) & 1 unit & $\begin{array}{l}\text { \$1229 (Capital), } \\
\text { \$1229 (Replacement), } \\
\text { \$10 per year } \\
\text { (Operation \& management) }\end{array}$ & - & $0-300$ units & $\begin{array}{l}\text { Nominal capacity: } \\
\text { 1156 Ah (6.94 kWh) } \\
\text { Lifetime throughput: } 9645 \mathrm{kWh} \\
\text { Nominal voltage: } 6 \mathrm{~V}\end{array}$ \\
\hline Converter & $1.0 \mathrm{~kW}$ & $\begin{array}{l}\text { \$1000 (Capital), } \\
\text { \$1000 (Replacement), } \\
\text { \$10 per year } \\
\text { (Operation \& management) }\end{array}$ & 15 & $0-400 \mathrm{~kW}$ & $90 \%$ efficiency \\
\hline
\end{tabular}

\section{Results}

The sustainable configuration, which contains PV panels, battery units, and a converter, is proposed based on the simulation results (Table 4). Table 5 summarizes the total and annual costs of the proposed configuration. The suggested configuration for providing reliable and sustainable energy services to SESM includes $500 \mathrm{~kW}$-capacity PV arrays, a $247 \mathrm{~kW}$-capacity converter, and 202 battery units (Table 4).

Table 4. Summary of the suggested configuration from the simulation results for SEMS.

\begin{tabular}{cccc}
\hline Components & Index & Components & Index \\
\hline PV array & $500 \mathrm{~kW}$-capacity & Wind turbine & 0 unit \\
Battery units & 202 units & Converter & $247 \mathrm{~kW}$-capacity \\
Initial capital cost & $\$ 870,258$ & Operating cost & $-\$ 14,965$ per year \\
Total net present cost & $\$ 623,617$ & Cost of energy & $\$ 0.464$ per kWh \\
Renewable fraction & 1.00 & & \\
\hline
\end{tabular}

Table 5. Costs of the suggested energy system configuration for SEMS.

\begin{tabular}{ccccccc}
\hline Cost Category & Component (\$) & Capital (\$) & Replacement (\$) & O\&M (\$) & Salvage (\$) & Total (\$) \\
\hline & PV array & 375,000 & 188,462 & 206,019 & $-119,010$ & 650,471 \\
& Grid connection & - & - & $-885,431$ & - & $-885,431$ \\
Total NPC (\$) & Battery units & 248,258 & 273,020 & 33,293 & $-96,296$ & 458,275 \\
& Converter & 247,000 & 147,432 & 40,709 & $-34,839$ & 400,302 \\
& System & 870,258 & 608,914 & $-605,410$ & $-250,145$ & 623,617 \\
\hline & PV array & 22,753 & 11,435 & 12,500 & -7221 & 39,467 \\
Annual cost (\$ per year) & Grid connection & - & - & $-53,723$ & - & $-53,723$ \\
& Battery units & 15,063 & 16,565 & 2020 & -5843 & 27,805 \\
& Converter & 14,986 & 8945 & 2470 & -2114 & 24,288 \\
& System & 52,802 & 36,945 & $-36,733$ & $-15,177$ & 37,837 \\
\hline
\end{tabular}

The estimated net present and annual costs are $\$ 623,617$ and $\$ 37,837$, respectively. The computed $\mathrm{COE}$ is $\$ 0.464$ per $\mathrm{kWh}$. Table 6 provides the annual electricity production. All the energy provided by the suggested system originates from renewable sources. As shown in Table 6, approximately $14 \%$ of 
the electricity produced by the suggested system fulfils the electricity demand of SEMS (AC primary load), while $86 \%$ is sold through the grid connection.

Table 6. Annual electricity consumption and production of the suggested configuration.

\begin{tabular}{cccccc}
\hline Load & $\begin{array}{c}\text { Consumption } \\
\text { (kWh Per year) }\end{array}$ & Fraction & $\begin{array}{c}\text { Component } \\
\text { (kWh Per year) }\end{array}$ & Production & Fraction \\
\hline AC primary load & 81,330 & 0.14 & PV array & 705,751 & 1.00 \\
Grid sales & 488,388 & 0.86 & Grid purchases & 0 & 0 \\
Total & 569,718 & 1.00 & Total & 705,751 & 1.00 \\
\hline
\end{tabular}

Altering the current grid connection to the suggested configuration is expected to reduce annual emissions of carbon dioxide, sulfur dioxide, and nitrogen oxide by $308,661 \mathrm{~kg}, 1338 \mathrm{~kg}$, and $654 \mathrm{~kg}$, respectively.

\section{Discussion and Conclusions}

To develop more sustainable and eco-friendly energy plans in South Korea, the government intends to distribute renewable energy generation facilities to public buildings and organizations. Considering this trend, this study introduces a potential sustainable renewable energy generation facility configuration to fulfil the electricity demand of SEMS using local, natural resources. To evaluate the suggested configurations of the simulations, both the COE and the NPC are computed and employed.

The suggested configuration achieves $100 \%$ renewable energy, with a COE of $\$ 0.464$. Although the COE of this configuration is higher than the current price of the South Korean grid connection [20], the suggested configuration can be applied to SEMS, a public education building in South Korea, as an on-site test. In addition, the simulation results also indicate that subsidies are an important issue in distributing and maintaining renewable energy production facilities [21].

As using renewable energy production facilities significantly reduces greenhouse gas emissions, the South Korean government and associated industries should distribute renewable energy production facilities [22]. According to the Paris Agreement, which introduces a mandatory level of greenhouse gas emissions for 195 nations, the South Korean government should also attempt to distribute more sustainable energy production facilities within its electricity system [23].

Although both economic and environmental information, which can be applied to the potential configuration of SEMS, was investigated considering subsidies for renewable energy production facilities in South Korea, this study has several limitations. First, the economic aspects of the certified reduction in greenhouse gas emissions were not considered. This can produce better economic results on utilizing renewable energy resources than the simulation results [24]. Second, economic theories in the renewable energy industry were not considered in the simulations. Several studies have already indicated that various economic theories can be applied and used in the renewable energy industry and market $[25,26]$. Therefore, future research should aim to eliminate the limitations of the current study.

Author Contributions: E.P. designed and wrote the majority of the manuscript. A.P.d.P. contributed to the analysis and revised the manuscript.

Funding: This work was supported by the Ministry of Education of the Republic of Korea and the National Research Foundation of Korea (NRF-2018S1A5A8027730). This research was also supported by the MIST, Korea, under the National Program for Excellence in SW supervised by the IITP (2015-0-00914). Moreover, the second author's research is funded by Ministerio de Economía y Competitividad (DPI2015-69041-R) and by Universitat Jaume I.

Conflicts of Interest: The authors declare no conflict of interest. 


\section{References}

1. Roh, S.; Kim, D. Effect of Fukushima accident on public acceptance of nuclear energy (Fukushima accident and nuclear public acceptance). Energy Sources Part B Econ. Plan. Policy 2017, 12, 565-569. [CrossRef]

2. Ministry of Trade, Industry and Energy (South Korea). South Korea Government, the Introduction of Re-Construction of New Kori Nuclear Plants and Energy Roadmap; Ministry of Trade, Industry and Energy: Sejong, Korea, 2017.

3. Korea, S. The Current Energy Status in Korea; Ministry of Trade, Industry and Energy: Sejong, Korea, 2017.

4. Kraxner, F.; Leduc, S.; Lee, W.; Son, Y.; Kindermann, G.; Patrizio, P.; Mesfun, S.; Yowargana, P.; Mac Dowall, N.; Yamagata, Y.; et al. Towards the Paris Agreement-Negative emission and what Korea can contribute. In Proceedings of the 19th EGU General Assembly, EGU2017, Vienna, Austria, 23-28 April 2017.

5. Chung, W.S.; Kim, S.S.; Moon, K.H.; Lim, C.Y.; Yun, S.W. A conceptual framework for energy security evaluation of power sources in South Korea. Energy 2017, 137, 1066-1074. [CrossRef]

6. Hong, H.; Choi, J.; Im, S. Renewable energy production by heat pump as renewable energy equipment. Korean J. Air-Cond. Refrig. Eng. 2017, 29, 551-557.

7. Lee, C.Y.; Huh, S.Y. Forecasting the diffusion of renewable electricity considering the impact of policy and oil prices: The case of South Korea. Appl. Energy 2017, 197, 29-39. [CrossRef]

8. Oh, S.D.; Yoo, Y.; Song, J.; Song, S.J.; Jang, H.N.; Kim, K.; Kwak, H.Y. A cost-effective method for integration of new and renewable energy systems in public buildings in Korea. Energy Build. 2014, 74, 120-131. [CrossRef]

9. Kim, H.; Baek, S.; Park, E.; Chang, H.J. Optimal green energy management in Jeju, South Korea-On-grid and off-grid electrification. Renew. Energy 2014, 69, 123-133. [CrossRef]

10. Park, E.; Kwon, S.J. Renewable energy systems for sports complexes: A case study. Proc. Inst. Civ. Eng. Energy 2017, 171, 49-57. [CrossRef]

11. Bae, K.; Shim, J.H. Economic and environmental analysis of a wind-hybrid power system with desalination in Hong-do, South Korea. Int. J. Precis. Eng. Manuf. 2012, 13, 623-630. [CrossRef]

12. Park, E.; Kwon, S.J.; Del Pobil, A.P. For a Green Stadium: Economic feasibility of sustainable renewable electricity generation at the Jeju world cup venue. Sustainability 2016, 8, 969. [CrossRef]

13. Park, E.; Kwon, S.J. Towards a Sustainable Island: Independent optimal renewable power generation systems at Gadeokdo Island in South Korea. Sustain. Cities Soc. 2016, 23, 114-118. [CrossRef]

14. Choi, H.J.; Han, G.D.; Min, J.Y.; Bae, K.; Shim, J.H. Economic feasibility of a PV system for grid-connected semiconductor facilities in South Korea. Int. J. Precis. Eng. Manuf. 2013, 14, 2033-2041. [CrossRef]

15. Park, E.; Kwon, S.J. Solutions for optimizing renewable power generation systems at Kyung-Hee University's Global Campus, South Korea. Renew. Sustain. Energy Rev. 2016, 58, 439-449. [CrossRef]

16. Park, E.; Yoo, K.; Ohm, J.Y.; Kwon, S.J. Case study: Renewable electricity generation systems on Geoje Island in South Korea. J. Renew. Sustain. Energy 2016, 8, 015904. [CrossRef]

17. Chae, W.K.; Lee, H.J.; Won, J.N.; Park, J.S.; Kim, J.E. Design and field tests of an inverted based remote microgrid on a Korean Island. Energies 2015, 8, 8193-8210. [CrossRef]

18. Park, E. Potentiality of renewable resources: Economic feasibility perspectives in South Korea. Renew. Sustain. Energy Rev. 2017, 79, 61-70. [CrossRef]

19. Dursun, B. Determination of the optimum hybrid renewable power generating systems for Kavakli campus of Kirklareli University, Turkey. Renew. Sustain. Energy Rev. 2012, 16, 6183-6190. [CrossRef]

20. KEPCO. Electric Rates Tables in Korea; Korea Electric Power Corporation: Naju, Korea, 2017.

21. Kwon, T.H. Is the renewable portfolio standard an effective energy policy?: Early evidence from South Korea. Util. Policy 2015, 36, 46-51. [CrossRef]

22. Kafle, S.; Parajuli, R.; Bhattarai, S.; Euh, S.H.; Kim, D.H. A review on energy systems and GHG emissions reduction plan and policy of the Republic of Korea: Past, present, and future. Renew. Sustain. Energy Rev. 2017, 73, 1123-1130. [CrossRef]

23. Larkin, A.; Kuriakose, J.; Sharmina, M.; Anderson, K. What if negative emission technologies fail at scale? Implications of the Paris Agreement for big emitting nations. Clim. Policy 2018, 18, 690-714. [CrossRef]

24. Ishikawa, J.; Okubo, T. Greenhouse-Gas Emission Controls and Firm Locations in North-South Trade. Environ. Resour. Econ. 2017, 67, 637-660. [CrossRef] 
25. Lesser, J.A.; Su, X. Design of an economically efficient feed-in tariff structure for renewable energy development. Energy Policy 2008, 36, 981-990. [CrossRef]

26. Traber, T.; Kemfert, C. Impacts of the German support for renewable energy on electricity prices, emissions, and firms. Energy J. 2009, 30, 155-178. [CrossRef]

(C) 2018 by the authors. Licensee MDPI, Basel, Switzerland. This article is an open access article distributed under the terms and conditions of the Creative Commons Attribution (CC BY) license (http:// creativecommons.org/licenses/by/4.0/). 